\title{
The use of gloves by the nursing team in a hospital environment
}

\author{
O uso de luvas pela equipe de enfermagem em ambiente hospitalar \\ Utilización de guantes por el equipo de enfermería en el entorno hospitalario
}

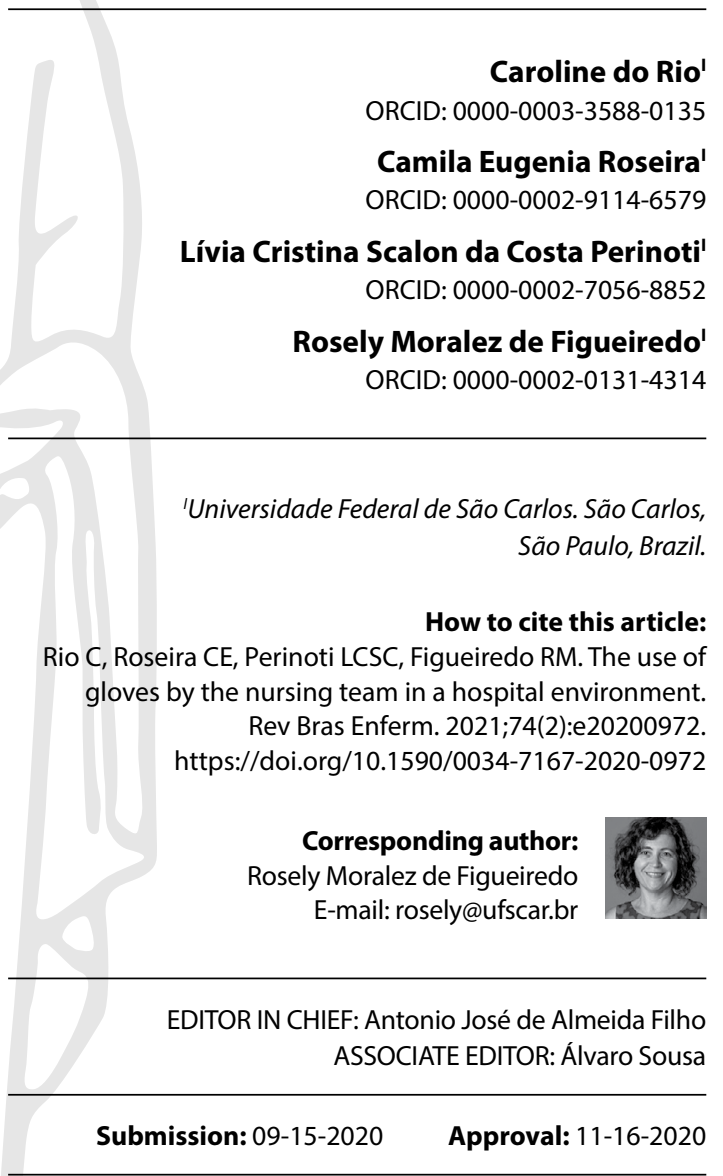

\begin{abstract}
Objectives: to verify the compliance rate of the use of gloves by the nursing team in a hospital environment. Methods: a descriptive study, carried out in a hospital in the state of Sao Paulo, Brazil, between August and October 2019, through the observation of the nursing team in carrying out a total of 396 procedures. All ethical aspects were considered. Results: 32 different types of procedures were observed. The compliance rate with the use of gloves occurred only in one observation (0.25\%). Excluding hand hygiene, it was $60.1 \%(238)$. In other 158 (39.9\%) opportunities, incorrect use varied between reuse (18.43\%), unnecessary use $(8.33 \%)$ and non-use when necessary (13.13\%). Hands were cleaned before using gloves in $1.76 \%$ of the observations and in $4.54 \%$ immediately after their removal. Conclusions: non-conformities were identified in the use of gloves when observing the performance of procedures by the nursing team.
\end{abstract}

Descriptors: Gloves, Protective; Nursing, Team; Cross Infection; Communicable Diseases; Nursing Service, Hospital.

\section{RESUMO}

Objetivos: verificar a taxa de conformidade do uso de luvas pela equipe de enfermagem em ambiente hospitalar. Métodos: estudo descritivo, realizado em hospital do interior do estado de São Paulo, Brasil, entre agosto e outubro de 2019, por meio da observação da equipe de enfermagem na realização de 396 procedimentos. Todos os aspectos éticos foram contemplados. Resultados: foram observados 32 diferentes tipos de procedimentos. A taxa de conformidade ao uso de luvas ocorreu somente em uma observação (0,25\%). Excluindo-se a higienização das mãos, essa taxa foi de 60,1\% (238). Em outras $158(39,9 \%)$ oportunidades, a utilização incorreta variou entre reutilização (18,43\%), utilização sem necessidade $(8,33 \%)$ e não utilização quando necessário (13,13\%). As mãos foram higienizadas previamente ao uso de luvas em $1,76 \%$ das observações e em 4,54\% imediatamente após sua retirada. Conclusões: foram identificadas não conformidades no uso de luvas na observação da execução de procedimentos realizados pela equipe de enfermagem.

Descritores: Luvas Protetoras; Equipe de Enfermagem; Infecção Hospitalar; Doenças Transmissíveis; Serviço Hospitalar de Enfermagem.

\section{RESUMEN}

Objetivos: comprobar la tasa de conformidad del uso de guantes por el equipo de enfermería en el entorno hospitalario. Métodos: se trata de un estudio descriptivo, realizado en un hospital del interior del estado de São Paulo, Brasil, entre agosto y octubre de 2019, mediante observación del equipo de enfermería en la realización de 396 procedimientos. Se contemplaron todos los aspectos éticos. Resultados: se observaron 32 tipos diferentes de procedimientos. Hubo conformidad en el uso de guantes solamente en una observación $(0,25 \%)$. Excluyendo la higiene de las manos, la tasa fue del 60,1\% (238). En 158 (39,9\%) oportunidades, el uso incorrecto osciló entre la reutilización (18,43\%), el uso sin necesidad $(8,33 \%)$ y la no utilización cuando era necesario $(13,13 \%)$. Las manos se higienizaron antes del uso de los guantes en el $1,76 \%$ de las observaciones y en el $4,54 \%$, inmediatamente después de su retirada. Conclusiones: se identificaron no conformidades en la utilización de guantes durante la observación de la ejecución de procedimientos realizados por el equipo de enfermería.

Descriptores: Guantes Protectores; Grupo de Enfermería; Infección Hospitalaria; Enfermedades Transmisibles; Servicio de Enfermería en Hospital. 


\section{INTRODUCTION}

In health services, gloves are the most used inputs, since the Acquired Immunodeficiency Syndrome (HIV/AIDS) epidemic in the 1980s, when the Centers for Disease Control and Prevention (CDC) instituted the "Universal Precautions", currently named "Standard Precautions" (SP), highlighting the need for all health workers to wear gloves through possible contact with body fluids, since these were the means of pathogen transmission ${ }^{(1)}$.

In this context, the gloves are inserted in the PE, which converge to the adoption of a set of prevention practices during the health care along with Hand Hygiene $(\mathrm{HH})$ and the use of other Personal Protective Equipment (PPE) - such as masks, apron and protective glasses - respiratory label, waste management and immunization of the professional ${ }^{(2)}$.

The protection mechanism of health professionals, through the use of gloves, occurs from the reduction of direct contact of the professionals' hands with the patients' unhealthy tissues, lesions or mucous membranes, for example, during procedures ${ }^{(3)}$ such as venipuncture, disregard for diuresis, aspiration of the airways.

However, care must be taken to ensure that it is used in a rational manner. Researches ${ }^{(3-4)}$ state that the indiscriminate use of gloves, as well as the unnecessary use of sterile gloves, generates costs to the health service, greater awareness of latex and increases the risk of cross-infection among patients, since this situation tends to be combined with low adherence to $\mathrm{HH}$.

In line with the aforementioned statement, another study ${ }^{(5)}$ highlighted that the use of gloves does not alter the need to use the five moments of hygiene, that is, the use of gloves does not replace hand hygiene at any of the necessary times.

Unsafe practices such as the absence of $\mathrm{HH}$ and the inappropriate use of gloves are related to the spread of microorganisms ${ }^{(3-4)}$ and, consequently, to Health Care Related Infections (HCRI).

Therefore, the Epidemiological Surveillance Center from the Sao Paulo State ${ }^{(6)}$ created a strategy for recommending the use of gloves to provide health professionals with guidelines for the rational use of this equipment. This material addresses the indication of the moments relevant to its use, the importance of preventing accidents with biological material, risks of not using it, among others, so that professionals could be informed about the risk of exposure to body fluids and the type of glove to be used in different situations.

According to the World Health Organization $(\mathrm{WHO})^{(7)}$, the change of gloves is necessary whenever moving with different microbial loads, when assisting the same patient, and when caring for different patients, in order to avoid transmission of microorganisms among different locations in the same patient, between different patients and from patients to surfaces and equipment. The guide continues to reinforce that $\mathrm{HH}$ must be performed before and after each change of gloves.

Data $^{(5)}$ suggest that the use of gloves has been extended indiscriminately to a wide range of clinical activities that do not involve exposure to body fluids, making the professional not responsible for analyzing the risk that the procedure offers and only then deciding whether or not to use them. The extended use of gloves decreases the opportunities of $\mathrm{HH}$ collaborating to increase the risk of cross infection.
Therefore, by wearing gloves indiscriminately, in an attempt to reduce the risk of infection, healthcare professionals can actually increase the transmission of microorganisms between the environment and the patient and among different patients, whether due to the lack of $\mathrm{HH}$ before and after removing them, or even for not removing gloves to perform procedures on different patients and manipulate equipment ${ }^{(5)}$.

Thus, researches ${ }^{(8)}$ identified non-conformities in adhering to the use of gloves with regard to the high rate of reuse and also their absence when indicated.

A study ${ }^{(3)}$ indicated that there is no consensus among nursing professionals regarding the use of gloves in different activities. In addition, it is possible to infer that misconceptions lead to inappropriate practices and, consequently, expose patients and professionals to unnecessary risks.

In view of the losses inherent in the incorrect use of gloves and not guided by the risk assessment and the frequent use of gloves by the nursing team in direct patient care, it was proposed to conduct this study, where the compliance rate was verified of the use of gloves by the nursing team in a hospital environment.

\section{OBJECTIVES}

To verify the compliance rate of the use of gloves by the nursing team in a hospital environment.

\section{METHODS}

\section{Ethical aspects}

It should be noted that resolution $466 / 12^{(9)}$ was respected and the project was approved by the Research Ethics Committee with Human Beings at UFSCar. All participants signed the Informed Consent Form.

\section{Design, period and setting of study}

This is a descriptive study, through observation of the nursing team during the performance of a total of 396 procedures to assess the compliance rate with the use of gloves. The research took place at Santa Casa de Misericordia of Sao Carlos, a hospital located in the city of Sao Carlos, SP that also covers the population of the micro-region.

The collections took place in three sectors of medical and surgical clinic, totaling 190 beds, from August to October 2019, four to five times a week, for five to six hours a day. Each opportunity was observed exclusively from the beginning until its completion, only afterwards to start another observation. The study was guided by the Strengthening the Reporting of Observational Studies in Epidemiology (STROBE) ${ }^{(10)}$.

\section{Population, inclusion and exclusion criteria}

Of the 40 nursing professionals ( 12 nurses and 28 technicians), from daytime working in the units studied, 28 accepted to participate in the study, 20 technicians and 08 nurses. To calculate the total opportunities to be observed, we used the OpenEpi ${ }^{\circ}$ software ${ }^{(11)}$, with a $95 \%$ confidence interval, which indicated the minimum sample size of 384 observations. 
It is noteworthy that the inclusion criteria were: being a nursing professional (nurses, technicians or assistants) and working at the place of study during the day. In order not to compromise the patients' sleep schedule, the study did not include data collection at night.

\section{Study protocol}

For data collection, a structured script was developed by the researchers, based on WHO recommendations ${ }^{(7)}$ for the use of gloves. In summary, the use of gloves is recommended in the following cases: before a sterile procedure; before contact with blood or body fluid, regardless of whether it is a sterile condition; contact with patients in precaution and contact with their environment. On the other hand, gloves should be removed when there is a suspicion or confirmation of loss of integrity; when contact with blood/body fluid ends; when contact with patient and his/her surroundings ends, or a contaminated body area; hands must be sanitized before putting on gloves and immediately after its removal ${ }^{(7)}$. During the observations, the percentage of times the procedure was performed in accordance with each of the criteria described above (compliance rate) was identified. Observations where the performance of the procedure did not follow any of these criteria were recorded as non-conforming in the specific item where the non-conformity occurred.

Each procedure (opportunity) was observed exclusively from start to finish, only to start observing a new procedure.

To guarantee the anonymity and confidentiality of the professional participating in the study, the observations were made according to the appearance of opportunities, regardless of the professional who performed it.

\section{Data analysis}

The collected data were organized and stored in a database using the Microsoft Excel $2016^{\circledR}$ program with subsequent descriptive statistical analysis.

\section{RESULTS}

A total of 396 procedures were observed, ranging from those with low risk of biological exposure, such as vital signs measurement (SM), to high-risk procedures, such as management of vascular access, as shown in Table 1.

In isolation, the most frequently observed procedures were: diaper change (9.34\%), bed bath (7.07\%), changing sheets $(5.55 \%)$, Measurement of vital signs (5.30\%) and dressing (5.05\%), each presenting different degrees of risk of exposure to biological material.

Table 2 shows the absolute frequencies (related to the total of observations) and the compliance rate (percentage of observations in which the professional adhered to the use of the glove properly) of the opportunities observed.

The moment of $\mathrm{HH}$ before putting on the gloves was considered when the professional enters the patients' room, prepared to perform the procedure, and sanitize their hands with $70 \%$ alcohol gel allocated in each patients' bed. Thus, in just $1.76 \%$ (7) of the opportunities, $\mathrm{HH}$ was performed before the procedure, that is, in $98.24 \%$ (389) the gloves were worn without prior hand hygiene.
Table 1 - Absolute and relative frequency of the use of gloves by type of observed procedures, São Carlos, São Paulo, Brazil, 2020, (N=396)

\begin{tabular}{lcc}
\hline Observed procedures & $\begin{array}{c}\text { Absolute } \\
\text { Frequency } \\
\text { (n) }\end{array}$ & $\begin{array}{c}\text { Relative } \\
\text { Frequency } \\
\%\end{array}$ \\
\hline Vascular access management* & 214 & 54.04 \\
Diaper change & 37 & 9.34 \\
Bed bath & 28 & 7.07 \\
Changing sheets & 22 & 5.55 \\
Measurement of vital signs & 21 & 5.30 \\
Curative & 20 & 5.05 \\
Containment of patient in bed & 7 & 1.77 \\
Others** & 6 & 1.51 \\
Diuresis control (despise diuresis) & 6 & 1.51 \\
Enteroclysm & 5 & 1.26 \\
Administration of enteral diet & 4 & 1.01 \\
Administration of medication by nasogastric tube & 4 & 1.01 \\
Decubitus change & 4 & 1.01 \\
Administration of subcutaneous medication & 3 & 0.76 \\
Administration of oral medication & 3 & 0.76 \\
Inhalation system installation & 3 & 0.76 \\
Nasogastric tube & 3 & 0.76 \\
Electrocardiogram & 2 & 0.50 \\
Bladder irrigation installation & 2 & 0.50 \\
Patient transport & 2 & 0.50 \\
TOTAL & 396 & 100 \\
\hline Not * & & \\
\hline
\end{tabular}

Note: *Intravenous medication, venous and arterial puncture, capillary blood glucose; **Breast milking, oral hygiene, handling of urinary catheter, aid in aspiration, aid in probing, urine collection.

Table 2 - Distribution of the nursing professionals' compliance rate in view of glove use opportunities observed, São Carlos, São Paulo, Brazil, 2020, (N=396)

\begin{tabular}{|c|c|c|c|c|}
\hline $\begin{array}{l}\text { Steps involved in the } \\
\text { use of gloves }\end{array}$ & $\begin{array}{l}\text { Yes } \\
(n / \%)\end{array}$ & $\begin{array}{c}\text { No } \\
(\mathbf{n} / \%)\end{array}$ & $\begin{array}{l}\text { Not } \\
\text { applicable } \\
\text { (n/\%) }\end{array}$ & $\begin{array}{l}\text { Compliance } \\
\text { rate } \\
\text { (n/\%) }\end{array}$ \\
\hline $\begin{array}{l}\text { Sanitized hands before } \\
\text { putting on gloves }\end{array}$ & 7 & 389 & ----- & 1.76 \\
\hline Used new gloves & 238 & 158 & ---- & 60.10 \\
\hline $\begin{array}{l}\text { Only the place where the } \\
\text { procedure was performed } \\
\text { touched the patient }\end{array}$ & 313 & 31 & 52 & 79.04 \\
\hline $\begin{array}{l}\text { Did not touch surfaces of } \\
\text { the patient's unit before } \\
\text { performing the procedure }\end{array}$ & 247 & 97 & 52 & 62.37 \\
\hline $\begin{array}{l}\text { Did not touch surfaces } \\
\text { of the patient's unit after } \\
\text { performing the procedure }\end{array}$ & 229 & 115 & 52 & 57.82 \\
\hline $\begin{array}{l}\text { Removed the gloves } \\
\text { immediately after the } \\
\text { procedure }\end{array}$ & 195 & 149 & 52 & 49.24 \\
\hline $\begin{array}{l}\text { Discarded them in infectious } \\
\text { garbage }\end{array}$ & 261 & 83 & 52 & 65.9 \\
\hline $\begin{array}{l}\text { Hand sanitized after } \\
\text { removing gloves }\end{array}$ & 18 & 326 & 52 & 4.54 \\
\hline
\end{tabular}

As for the use of gloves, it was identified that in $60.1 \%$ (238) of the observations, professionals correctly used new gloves to perform a procedure that required their use. In other $39.9 \%$ (158) opportunities observed, the use was not correct.

The non-compliance with the use of gloves, observed in $39.9 \%$ (158) of the opportunities, occurred as follows: in $18.43 \%$ (73) of the times, the professional reused the same glove for at least 
twice, in the same patient or different patients; in $13.13 \%$ (52) of the opportunities, the professional did not use gloves, even though its use was recommended for the performance of that procedure; and, finally, in $8.33 \%$ (33) of the observations, the professional used gloves, even though it was not recommended its use in that situation.

The next step was to observe whether the professional wearing gloves touched the patient only at the site of the procedure, which occurred in $79.04 \%$ (313) of the opportunities. In 7.82\% (31) of the observations, the professional previously touched other places of the patient, without being exclusively the site indicated.

Next, it was analyzed whether the professional touched the patient's unit (bed, bedside table, serum support, among others) wearing gloves before performing the procedure. This fact occurred in $24.49 \%$ (97) of the observations.

Equally, it was observed whether the professionals touched the patients' unit using gloves after the procedure was performed. The result obtained was that only in $57.82 \%$ (229) of the cases this did not occur, that is, the gloves were removed after performing the procedure without touching other surfaces. In $29.04 \%$ (115) observations, health professionals touched some place in the patients' unit after performing the procedure wearing gloves.

As for the moment of removing the gloves, after the end of the procedure, it was observed that in only $49.24 \%$ (195) of the observations, the professionals removed the gloves immediately after performing the procedures.

As for the disposal of gloves, it was considered as correct the one carried out on infective white trash (as standardized in the institution studied), which totaled $65.9 \%$ (261) of the opportunities. In $20.95 \%$ (83) of the observations, the gloves were not correctly discarded and $13.13 \%$ (52) of the total observed was considered not applicable, due to the professionals not having used gloves, although indicated.

For the moment of $\mathrm{HH}$, after removing gloves, only $4.54 \%$ (18) of the opportunities were performed correctly, that is, in $82.32 \%$ (326) of the observations made, there was no hand hygiene after removing the gloves. In $13.13 \%$ (52) of the total cases, the situation was considered not applicable due to professionals who had not their gloves on previously.

\section{DISCUSSION}

It was observed in this study that in view of 396 opportunities to use gloves, only one $(0.25 \%)$ of them occurred in agreement with all the necessary steps, including the correct hand hygiene. This low adherence to $\mathrm{HH}$ by nursing professionals is corroborated by the literature in several countries ${ }^{(8,12-13)}$.

A study carried out in the hemodialysis sector, in Sao PauloBrazil, shows that the $\mathrm{HH}$ rate before procedure was only $6.4 \%$ and after procedure, $27.0 \%$. These data suggest that professionals recognize the importance of $\mathrm{HH}$ more for their own protection than for patient safety ${ }^{(8)}$. A study ${ }^{(12)}$ carried out in the United States, which evaluated the beliefs and practices of the use of gloves by health professionals in various hospital sectors, showed that in 3821 of the observations, to enter rooms in contact precautions, the gloves were used in $78 \%$ of the time. However, prior $\mathrm{HH}$ was performed only $42 \%$ of the time, and this rate was repeated in another 1136 observations before entering common rooms without specific precautions, pointing out that the use of gloves can cause professionals reduce their attention to the moments when it is necessary to perform the $\mathrm{HH}$, even in situations of contact precautions.

In Sri Lanka, a research ${ }^{(13)}$ that aimed to describe adherence to infection control practices in relation to neonatal care by nursing team and physicians, found that $\mathrm{HH}$ before the use of gloves was performed by $33.3 \%$ of professionals in the operating room (before handling neonates) and $57.1 \%$ in the delivery room, unlike those working in the Neonatal Intensive Care Unit, in which the percentage was quite satisfactory, $96 \%$. Despite the knowledge about the stages and the importance of $\mathrm{HH}$ seem to be something well established for the nursing team, other factors can influence, such as an intensive care environment, which can give the professionals who work in it the false impression that $\mathrm{HH}$ is more necessary as it is an imminent risk sector.

To prove this, a study carried out in Japan ${ }^{(14)}$, in which nurses answered a questionnaire about adherence to the use of PPE, when asked if $\mathrm{HH}$ is necessary after removing gloves, $98.9 \%$ of participants responded positively, showing that despite knowledge is present, it is not always what happens in practice.

As for the incorrect use of gloves, a rate of $39.89 \%$ was observed in this study, which varied between reuse, unnecessary use and non-use even if necessary. This data is similar to the research ${ }^{(8)}$ in which the incorrect use of gloves, reuse and absence of use was greater than $54 \%$ of the opportunities observed. It is known that the indiscriminate or inappropriate use of gloves can be associated with the transmission of pathogens and cross-contamination ${ }^{(15)}$.

Regarding unnecessary use, authors ${ }^{(16)}$ point out that there is a culture of indiscriminate use of gloves, which are used regardless of the risk of contact with blood, secretions or mucous membranes, a finding corroborated by research ${ }^{(12)}$ in which health professionals interviewed also reported the use of gloves in cases where they were not necessary, such as in any contact with patients and handling of equipment. In this research, the use of gloves without indication occurred in $8.33 \%$ of the opportunities observed.

As for the reuse of gloves, a fact identified in $18.43 \%$ of the opportunities observed, it was found that the gloves were reused at least twice in the same patient or even in different ones. Similar results are presented in two Brazilian studies: the first one ${ }^{(8)}$, showed that the gloves were reused in $25 \%$ of the observations in the hemodialysis sector; and the other one ${ }^{(17)}$ was performed in a hospital environment that observed the use of the same glove in different procedures in more than one patient, with emphasis on the installation of inhalation, exchange of the serum $/$ medication bottle and measurement of vital signs.

Regarding the opinion of nurses on this subject, a study carried out in Rio de Janeiro ${ }^{(18)}$ indicates that they do not consider changing gloves between one patient and another as a priority, nor changing procedures in the same patient. These data are corroborated by a research in Japan ${ }^{(14)}$, where $97.8 \%$ of nurses interviewed answered that there is no need to change gloves when performing different care in the same patient.

In $24.49 \%$ of the observations made, the professionals touched the patients'surfaces wearing gloves before performing the procedure. This non-conformity is extremely worrying, since the professional 
can make the surface hygiene become invalid, allowing the crosstransmission of microorganisms and the occurrence of $\mathrm{HCRI}^{(19)}$.

Still regarding the inappropriate use of gloves, a worrying situation found in this study was that in $13.13 \%$ of the opportunities, professionals did not use gloves even though they had the indication for use. This fact is also in accordance with the literature, as in the study carried out in the state of Sao Paulo(20), in which $25.0 \%$ of the professionals injured by percutaneous occupational exposures involving a hollow needle were not wearing procedure gloves.

A study ${ }^{(17)}$ highlights that there is low adherence to the use of gloves when administering medications subcutaneously and intramuscularly (26,9\%), capillary blood glucose (40\%) and manipulation of the venous network (40\%). The authors also report that there are protocol differences in different institutions regarding the indication of the use of gloves for intramuscular and subcutaneous injections, which can make it difficult for the conducts to be uniformly developed. It should be noted that, according to WHO recommendations ${ }^{(21)}$ the use of gloves is not mandatory when administering medications subcutaneously and intramuscularly, only in cases of manipulation of the venous network.

\section{Limitations of the Study}

This study had as limitation the fact that it was not possible to present the results of conformity or non-conformity of the use of gloves, according to the procedure performed. This was due to the operationalization of the study and it was necessary to fragment the observation of the procedure in stages that involved the use of gloves. Thus, the same procedure could involve more than one step and result in the use of different gloves in each one.

Another point considered as a limitation was the observation only of performing or not hand hygiene, without assessing its quality. It was understood that this evaluation could affect the observation of the initial objective of the study, in addition to the evaluation of hand hygiene not being one of the objectives of this research.

\section{Contributions to the area of nursing}

When evidencing the weaknesses in nursing professionals' adherence to the use of gloves, this study contributes to direct reflexive actions of work processes and more specific educational interventions aiming to transform this scenario. In addition, it can provide future research that point to successful strategies to expand the use of gloves.

\section{CONCLUSIONS}

We concluded that the observation of the nursing team in the execution of procedures identified situations of non-compliance in the use of gloves. The non-conformities occurred due to the lack of hand hygiene before and after removing gloves, by reusing gloves, its non-use in indicated situations and its use when not needed.

We understand that these non-conformities can compromise the safety of the assistance provided by the professional, spreading microorganisms to other patients and environment, in addition to their own safety, with their exposure to biological material when not wearing gloves when indicated.

Observation of practice studies are essential for evaluating educational programs and analyzing work processes. Therefore, it should be encouraged. We believe that the data found here can give visibility to the non-conformities present in a practice as common as the use of PPE gloves and, at the same time, so closely related to the prevention of HCRIs.

\section{FUNDING}

Work extracted from a Scientific Initiation project funded by the São Paulo Research Support Foundation (FAPESP) - Process 2019/08484-3.

This work was carried out with the support of the Coordination for the Improvement of Higher Education Personnel - Brazil (CAPES) - Financing Code 001.

\section{REFERENCES}

1. Siegel JD, Rhinehart E, Jackson M, Chiarello L. Guideline for isolation precautions: preventing transmission of infectious agents in healthcare settings and the Healthcare Infection Control Practices Advisory Committee [Internet]. 2007 [cited 2020 Jan 20]. Available from: https:// www.cdc.gov/infectioncontrol/guidelines/isolation/index.html

2. Aguiar DF, Lima ABG, Santos RB. Uso das precauções-padrão na assistência de enfermagem: um estudo retrospectivo. Esc Anna Nery [Internet]. 2008 [cited 2020 Jan 20];12(3):571-5. Available from: https://www.redalyc.org/articulo.oa?id=127715320027

3. Ferreira AM, Bertolo D, Andrade MR, Andrade D. Conhecimento da equipe de enfermagem acerca do uso de luvas no contexto hospitalar. Rev Eletr Enf [Internet]. 2009 [cited 2020 Feb 05];11(3):628-34. Available from: http://www.fen.ufg.br/revista/v11/n3/v11n3a21.htm

4. Santos TCR, Roseira CE, Piai-Morais TH, Figueiredo RM. Hand hygiene in hospital environments: use of conformity indicators. Rev Gaúcha Enferm. 2014; 35(1):70-77. https://doi.org/10.1590/1983-1447.2014.01.40930

5. Wilson J, Prieto J, Singleton J, O'Connor V, Lynam S, Loveday H. The misuse and overuse of non-sterile gloves: application of an audit tool to define the problem. J Infect Prev. 2015;16(1):24-31. https://doi.org/10.1177/1757177414558673

6. Governo do Estado de São Paulo. Secretaria de Estado da Saúde. Centro de Vigilância Epidemiológica. Divisão de infecção hospitalar Recomendações sobre o uso de luvas em serviços de saúde[Internet]. 2016 [cited 2020 Jan 25]. Available from: http://www.saude.sp.gov.br/ resources/cve-centro-de-vigilancia-epidemiologica/areas-de-vigilancia/infeccao-hospitalar/bmr/doc/ih16_bmr_uso_luvas.pdf

7. World Health Organization (WHO). World Health Organization Guidelines on Hand Hygiene [Internet]. Geneva: WHO, 2009 [cited 2019 Dec 14]. Available from: http://apps.who.int/iris/bitstream/handle/10665/44102/9789241597906_eng.pdf;jsessionid=94BB1D94D70E3D382CCB 07DA3100D769? sequence $=1$ 
8. Silva DM, Marques BM, Galhardi NM, Orlandi FS, Figueiredo RM. Hands hygiene and the use of gloves by nursing team in hemodialysis service. Rev Bras Enferm. 2018;71(4):1963-9. https://doi.org/10.1590/0034-7167-2017-0476

9. Ministério da Saúde (BR). Resolução n 466, de 12 de dezembro de 2012 [Internet]. Conselho Nacional de Saúde, Brasília 2012 [cited 2020 Mar 05]. Available from: http://conselho.saude.gov.br/resolucoes/2012/Reso466.pdf

10. Elm E von, Altman DG, Egger M, Pocock SJ, Gøtzsche PC, Vandenbroucke JP, et al. Strengthening the reporting of observational studies in epidemiology (STROBE) statement: guidelines for reporting observational studies BMJ 2007;335:806. https://doi.org/10.1136/ bmj.39335.541782.AD

11. Dean AG, Sullivan KM, Soe MM. OpenEpi: Open source epidemiologic statistics for public health, version. 2015.

12. Baloh J, Thom KA, Perencevich E, Rock C, Robinson G, Ward M, et al. Hand hygiene before donning nonsterile gloves: healthcare workers' beliefs and practices. Am J Infect Control. 2019;47(5):492-7. https://doi.org/10.1016/j.ajic.2018.11.015

13. Jayasinghe $C$, Abeysena $C$. Adherence to infection control practices in relation to neonatal care in major hospitals in a district of Sri Lanka. J Coll Commun Phys Sri Lanka. 2020;25(4):158-67. https://doi.org/10.4038/jccpsl.v25i4.8208

14. Morioka S, Tajima T, Sugiki Y, Hayakawa K, Ohmagari N. Adherence to personal protective equipment use among nurses in Japanese tertiary care hospitals: what determines variability? J Hosp Infect. 2020;104(3):344-9. https://doi.org/10.1016/j.jhin.2019.11.019

15. Burdsall DP, Gardner SE, Cox T, Schweizer M, Culp KR, Steelman VM, et al. Exploring inappropriate certified nursing assistant glove use in long-term care. Am J Infect Control. 2017;45(9):940-5. https://doi.org/10.1016/j.ajic.2017.02.017

16. Barratt R, Gilbert GL, Shaban RZ, Wyer M, Hor SY. Enablers of, and barriers to, optimal glove and mask use for routine care in the emergency department: an ethnographic study of Australian clinicians. Australas Emerg Care. 2020;23(2):105-13. https://doi.org/10.1016/j. auec.2019.10.002

17. Santos TCR, Roseira CE, Passos IPBD, Figueiredo RM. The use of gloves by nursing staff: transmission risk protection. Rev Enferm UFPE. 2013;7(11):6438-45. https://doi.org/10.5205/1981-8963-v7i11a12290p6438-6445-2013

18. Padilha JMFO, Sá SPC, Souza SR, Brum AK, Lima MVR, Guimarães TF. Glove use in nursing practice and its implications: a methodological study. O Braz J Nurs [Internet] 2016 [cited 2020 Apr 16];15(4):632-43. Available from: http://www.objnursing.uff.br/index.php/nursing/ article/view/5409

19. Frota OP, Ferreira AM, Rigotti MA, Andrade D, Borges NMA, Ferreira Jr MA. Effectiveness of clinical surface cleaning and disinfection: evaluation methods. Rev Bras Enferm [Internet]. 2020 [cited 2020 Oct 30];73(1):e20180623. https://doi.org/10.1590/0034-7167-2018-0623

20. Negrinho NBS, Malaguti-Toffano SE, Reis RK, Pereira FMV, Gir E. Factors associated with occupational exposure to biological material among nursing professionals. Rev Bras Enferm. 2017;70(1):126-31. https://doi.org/10.1590/0034-7167-2016-0472

21. World Health Organization (WHO). WHO best practices for injections and related procedures toolkit [Internet]. Geneva: WHO; 2010 [cited 2020 Oct 16]. Available from: https://apps.who.int/iris/bitstream/handle/10665/44298/9789241599252_eng.pdf;jsessionid=A70E233F9EC2 $05561608169 \mathrm{EC} 37995 \mathrm{~F} 0$ ?sequence $=1$ 